\title{
Design, synthesis, and computational studies on dihydropyrimidine scaffolds as potential lipoxygenase inhibitors and cancer chemopreventive agents
}

\author{
This article was published in the following Dove Press journal: \\ Drug Design, Development and Therapy \\ 17 February 2015 \\ Number of times this article has been viewed
}

\section{Katharigatta N Venugopala ${ }^{1,2}$ \\ Reshme Govender ${ }^{2}$ \\ Mohammed A Khedr ${ }^{1,3}$ \\ Rashmi Venugopala ${ }^{4}$ \\ Bandar E Aldhubiab' \\ Sree Harsha' \\ Bharti Odhav \\ 'Department of Pharmaceutical \\ Sciences, College of Clinical \\ Pharmacy, King Faisal University, \\ Al-Ahsa, Kingdom of Saudi Arabia; \\ ${ }^{2}$ Department of Biotechnology and \\ Food Technology, Durban University \\ of Technology, Durban, South Africa; \\ ${ }^{3}$ Department of Pharmaceutical \\ Chemistry, Faculty of Pharmacy, \\ Helwan University, Ein Helwan, Cairo, \\ Egypt; ${ }^{4}$ Department of Public Health \\ Medicine, University of KwaZulu- \\ Natal, Howard College Campus, \\ Durban, South Africa}

Correspondence: Katharigatta $\mathrm{N}$

Venugopala

Department of Pharmaceutical Sciences,

College of Clinical Pharmacy, King Faisal

University, PO Box number 400, Al-Ahsa

31982, Kingdom of Saudi Arabia

Tel +966 I3 5898842

Fax +966 I3 58I 7174

Email kvenugopala@kfu.edu.sa

Bharti Odhav

Department of Biotechnology and Food Technology, Durban University of Technology, Steve Biko Campus,

S9, LI, Durban 400I, South Africa

Tel +273 I 3735330

Fax +2731 373535

Email odahvb@dut.ac.za

\begin{abstract}
Dihydropyrimidine scaffold has a wide range of potential pharmacological activities such as antiviral, antitubercular, antimalarial, anti-inflammatory, and anticancer properties. 5-Lipoxygenase enzyme is an enzyme responsible for the metabolism of arachidonic acid to leukotrienes. The elevated levels of this enzyme and its metabolites in cancer cells have a direct relation on the development of cancer when compared to normal cells. The development of novel lipoxygenase inhibitors can have a major role in cancer therapy. A series of substituted 1,4-dihydropyrimidine analogues were synthesized and characterized by ${ }^{1} \mathrm{H}-\mathrm{NMR},{ }^{13} \mathrm{C}-\mathrm{NMR}$, and HRMS. Molecular docking against lipoxygenase enzyme (protein data bank code =3V99) was done using Molecular Operating Environment 2013.08 and Leadit 2.1.2 softwares and showed high affinities. The synthesized compounds were tested for their lipoxygenase inhibitory activity and showed inhibition ranging from $59.37 \% \pm 0.66 \%$ to $81.19 \% \pm 0.94 \%$. The activity was explained by a molecular docking study. The title compounds were also tested for cytotoxic activity against two human cancer cell lines Michigan Cancer Foundation-7 and human melanoma cells and a normal peripheral blood mononuclear cell line.
\end{abstract}

Keywords: 1,4-dihydropyrimidines, synthesis and characterization, molecular docking study

\section{Introduction}

Dihydropyrimidines (DHPMs) are well-known scaffolds that are easily prepared through condensation reaction of urea/thiourea, $\beta$-ketoester, and aryl aldehyde. ${ }^{1}$ DHPM derivatives have a significant role in medicinal chemistry for various pharmacological activities, ${ }^{2,3}$ such as anticancer, ${ }^{4}$ antibacterial, ${ }^{5-7}$ antifungal, ${ }^{8}$ antihypertensive, antitubercular, ${ }^{9,10}$ antimalarial, ${ }^{11}$ antiviral, ${ }^{12,13}$ and anti-inflammatory ${ }^{14}$ activities . 5-Lipoxygenase is an enzyme responsible for the metabolism of arachidonic acid. It is found in plants and animals with high percentage of sequence identity especially in the catalytic site. ${ }^{15}$ 5-Lipoxygenase catalyzes the metabolism of arachidonic acid into hydroperoxyeicosatetraenoic acid and leukotrienes. The elevated levels of this enzyme have a direct relation to the development of cancer. ${ }^{16}$ The presence of high levels of lipoxygenase metabolites in many cancers, such as lung, prostate, breast, colon, skin, and brain cancers, has been reported. ${ }^{17}$ Inhibition of lipoxygenase may be an important target for the prevention of cancer and can occur through interfering with signaling cascade needed for cancer cell growth. Molecular modeling approach is widely used for the discovery, design, and prediction of the activity and mechanisms by which the active compounds act. Molecular docking is the 
process that predicts the orientation of all possible conformations of the tested compounds within the active site of the enzyme. It allows deriving all the features that are required for best interactions with the active enzyme site and for the optimization of any discovered lead compound. In addition, it can assist in studying the structure-activity relationship of the tested compounds. In continuation of our research on the development of novel heterocyclic compounds for various pharmacological activities ${ }^{18-20}$ and screening of pharmacologically active heterocyclic compounds for polymorphism property, ${ }^{21,22}$ the main aim of this work was to design, synthesize, and characterize some of the 1,4-dihydropyrimidine derivatives and to screen these compounds for their lipoxygenase inhibitory activity and cytotoxic activity against two cancer cell lines, such as Michigan Cancer Foundation-7 (MCF-7) and human melanoma cells (UACC-62), and a normal cell line, peripheral blood mononuclear cells (PBMCs), and to look for any promising activity. Molecular modeling study was performed to predict the mode of binding by which these compounds may inhibit lipoxygenase enzymes.

\section{Materials and methods}

Chemicals were procured from Merck \& Co., Inc. (Whitehouse Station, NJ, USA) and Sigma-Aldrich Co. (St Louis, MO, USA). Monitoring of chemical reactions was done on analytical thin-layer chromatography with Merck 60 F-254 silica-gel plates using solvent system ( $n$-hexane and ethylacetate [4:6]), and visualization was done with ultraviolet light. Büchi Melting Point B-545 apparatus was used to check melting points. NMR spectra $\left({ }^{1} \mathrm{H}\right.$ and $\left.{ }^{13} \mathrm{C}\right)$ were recorded in dimethyl sulfoxide (DMSO)- $d_{6}$ solvent using tetramethylsilane as an internal standard with a $400-\mathrm{MHz}$ Bruker spectrometer. Chemical shifts were showed in parts per million downfield from tetramethylsilane, and the splitting pattern is abbreviated as s, singlet; $\mathrm{m}$, multiplet; and $\mathrm{d}$, doublet. High-resolution mass spectrometry (HRMS) analysis was performed on a BrukerMicroTOF QII mass spectrometer in positive mode with internal calibration.

Molecular Operating Environment (MOE) 2013.08 package license was purchased from Chemical Computing Group Inc (Montreal, QC, Canada), ${ }^{23}$ and Leadit 2.1.2 software license was purchased from BioSolveIT GmbH ( Sankt Augustin, Germany). ${ }^{24,25}$

The synthetic strategy employed to produce DHPM1DHPM8 is illustrated in Figure 1. Synthesis of 1 and 2 was performed as per the reported procedures. ${ }^{9,26}$

\section{General procedure employed in the preparation of DHPMI-DHPM8}

A mixture of compound 2 (1 mmol), substituted phenyl/ benzyl amines ( $1 \mathrm{mmol})$, and potassium carbonate $(1 \mathrm{mmol})$ in isopropanol $(10 \mathrm{~mL})$ was refluxed for 15 hours as depicted in Figure 1. Thin-layer chromatography was used to monitor

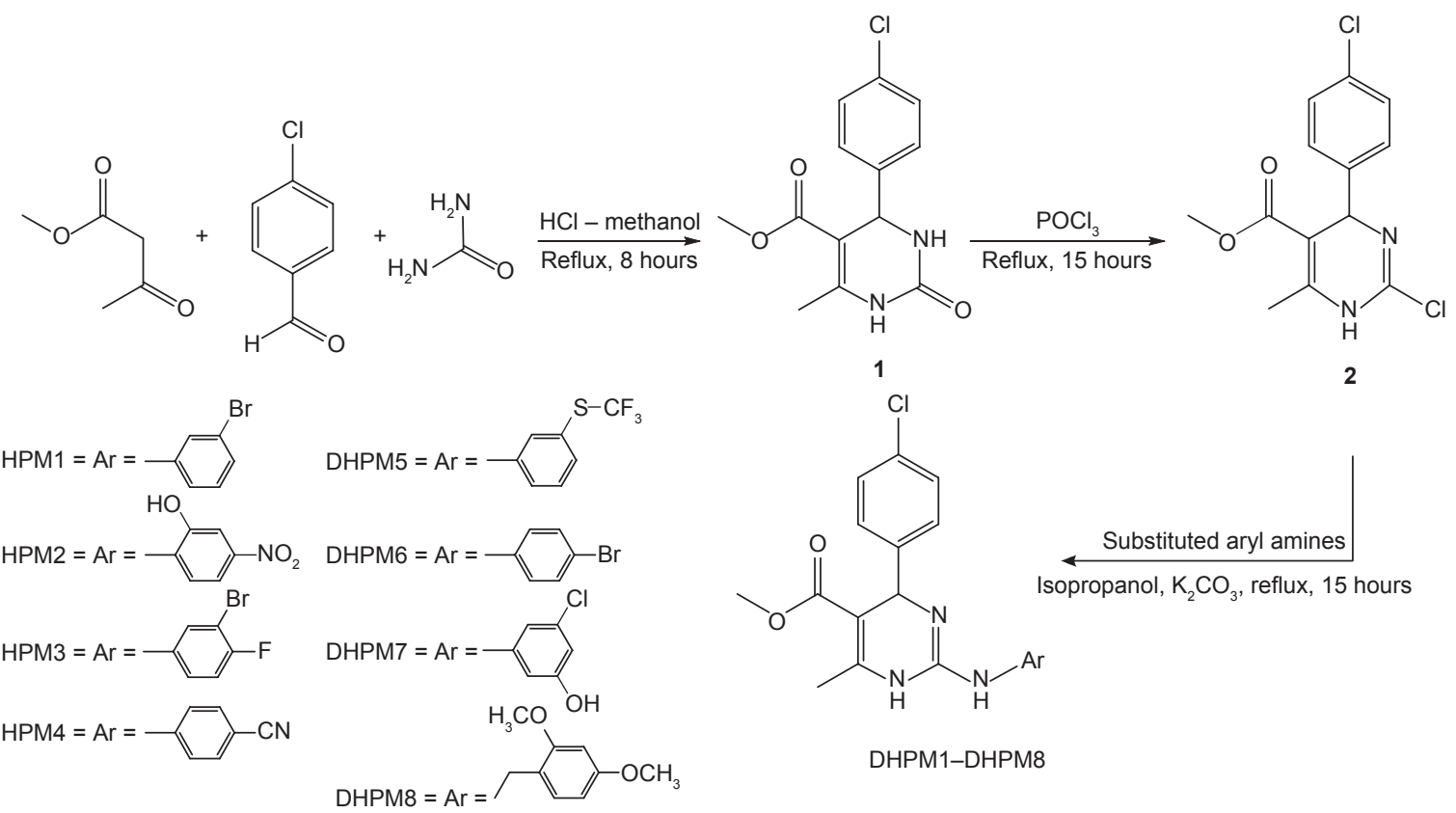

Figure I General route for the synthesis of I,4-dihydropyrimidine analogues DHPMI-DHPM8.

Abbreviation: DHPM, dihydropyrimidine. 
reaction completion. The product obtained was filtered, washed with isopropanol, and dried. Column chromatography was used to purify the crude product using $n$-hexane and ethylacetate $(4: 6)$ as eluent to obtain title compounds DHPM1-DHPM8 at 62\%-74\% yield. The physicochemical constants of the title compounds are tabulated in Table 1.

Methyl-2-(3-bromophenylamino)-4-(4chlorophenyl)-6-methyl- I,4-dihydropyrimidine5-carboxylate (compound DHPMI) Appearance: white solid. ${ }^{1} \mathrm{H}-\mathrm{NMR}\left(\mathrm{DMSO}-d_{6}\right) \delta 2.08$ (s, $\left.3 \mathrm{H},-\mathrm{CH}_{3}\right), 3.63\left(\mathrm{~s}, 3 \mathrm{H},-\mathrm{OCH}_{3}\right), 5.43(\mathrm{~s}, 1 \mathrm{H}), 7.21-7.53$ $(\mathrm{m}, 8 \mathrm{H}), 9.99(\mathrm{~s}, 1 \mathrm{H}), 11.1(\mathrm{~s}, 1 \mathrm{H}) \cdot{ }^{13} \mathrm{C}-\mathrm{NMR}$ (DMSO- $\left.d_{6}\right)$ $\delta 18.13,52.20,103.82,122.75,123.66,127.35,129.05$, $129.48,130.27,132.23,133.57,136.70,140.57,145.43$, 149.33, 165.18. HRMS calculated for $\mathrm{C}_{19} \mathrm{H}_{17} \mathrm{BrClN}_{3} \mathrm{O}_{2}$ 433.0193, found $434.0302(\mathrm{M}+\mathrm{H})^{+}$.

Methyl-4-(4-chlorophenyl)-2-(2-hydroxy-

4-nitrophenylamino)-6-methyl- I,4-dihydropyrimidine5-carboxylate (compound DHPM2)

Appearance: yellow solid. ${ }^{1} \mathrm{H}-\mathrm{NMR}$ (DMSO- $d_{6}$ ) $\delta 2.41$ (s, $\left.3 \mathrm{H},-\mathrm{CH}_{3}\right), 3.58\left(\mathrm{~s}, 3 \mathrm{H},-\mathrm{OCH}_{3}\right), 5.40(\mathrm{~s}, 1 \mathrm{H}), 6.82-7.53(\mathrm{~m}$, $4 \mathrm{H}), 8.1-8.16(\mathrm{~m}, 2 \mathrm{H}), 9.80(\mathrm{~s}, 1 \mathrm{H}), 10.28(\mathrm{~s}, 1 \mathrm{H}), 11.08(\mathrm{~s}$, $1 \mathrm{H}), 11.99$ (s, $1 \mathrm{H}) .{ }^{13} \mathrm{C}-\mathrm{NMR}$ (DMSO- $d_{6}$ ). $\delta 18.00,52.06$, 52.26, 103.62, 114.54, 117.31, 121.62, 124.46, 125.64, 129.08, 133.36, 139.75, 140.52, 145.12, 149.96, 159.59, 165.14. HRMS calculated for $\mathrm{C}_{19} \mathrm{H}_{17} \mathrm{ClN}_{4} \mathrm{O}_{5} 416.0887$, found $417.0990(\mathrm{M}+\mathrm{H})^{+}$.

Methyl-2-(3-bromo-4-fluorophenylamino)-4-(4chlorophenyl)-6-methyl-I,4-dihydropyrimidine-5carboxylate (compound DHPM3)

Appearance: white solid. ${ }^{~} \mathrm{H}-\mathrm{NMR}$ (DMSO- $\left.d_{6}\right) \delta 2.42(\mathrm{~s}, 3 \mathrm{H}$, $\left.-\mathrm{CH}_{3}\right), 3.60\left(\mathrm{~s}, 3 \mathrm{H},-\mathrm{OCH}_{3}\right), 5.35(\mathrm{~s}, 1 \mathrm{H}), 7.32-7.52(\mathrm{~m}, 6 \mathrm{H})$,
7.77-7.80 (d, 1H), $9.55(\mathrm{~s}, 1 \mathrm{H}), 10.52(\mathrm{~s}, 1 \mathrm{H}) .{ }^{13} \mathrm{C}-\mathrm{NMR}$ (DMSO- $d_{6}$ ) $\delta 18.07,52.04,52.41,103.30,116.71,116.94$, $120.99,121.25,123.06,123.16,129.18,129.30,129.75$, $131.84,131.93,133.37,140.63,145.05,150.13,160.60$, 163.09, 165.10. HRMS calculated for $\mathrm{C}_{19} \mathrm{H}_{16} \mathrm{BrClFN}_{3} \mathrm{O}_{2}$ 451.0098, found $452.0144(\mathrm{M}+\mathrm{H})^{+}$.

Methyl-4-(4-chlorophenyl)-2-(4-cyanophenylamino)6-methyl-I,4-dihydropyrimidine-5-carboxylate (compound DHPM4)

Appearance: yellow solid. ${ }^{1} \mathrm{H}-\mathrm{NMR}\left(\mathrm{DMSO}-d_{6}\right) \delta 2.38$ $\left(\mathrm{s}, 3 \mathrm{H},-\mathrm{CH}_{3}\right), 3.60\left(\mathrm{~s}, 3 \mathrm{H},-\mathrm{OCH}_{3}\right), 5.39(\mathrm{~s}, 1 \mathrm{H}), 7.32(\mathrm{~d}$, $4 \mathrm{H}), 7.45(\mathrm{~d}, 2 \mathrm{H}), 7.8(\mathrm{~d}, 2 \mathrm{H}), 10.77(\mathrm{~s}, 2 \mathrm{H}) .{ }^{13} \mathrm{C}-\mathrm{NMR}$ (DMSO- $d_{6}$ ) $\delta 18.76,51.84,52.65,102.77,106.84,119.29$, $122.87,128.59,129.27,133.08,134.17,141.74,143.04$, 147.56, 148.26, 165.55. HRMS calculated for $\mathrm{C}_{20} \mathrm{H}_{17} \mathrm{ClN}_{4} \mathrm{O}_{2}$ 380.1040, found $381.1126(\mathrm{M}+\mathrm{H})^{+}$.

Methyl 4-(4-chlorophenyl)-6-methyl-2-(3(trifluoromethylthio)phenylamino)- 1,4dihydropyrimidine-5-carboxylate (compound DHPM5) Appearance: pale yellow solid. ${ }^{1} \mathrm{H}-\mathrm{NMR}$ (DMSO- $d_{6}$ ) $\delta$ $2.42\left(\mathrm{~s}, 3 \mathrm{H},-\mathrm{CH}_{3}\right), 3.63\left(\mathrm{~s}, 3 \mathrm{H},-\mathrm{OCH}_{3}\right), 5.43(\mathrm{~s}, 1 \mathrm{H})$, 7.34-7.62 (m, 8H), 9.99 (s, 1H), 10.98 (s, 1H). ${ }^{13} \mathrm{C}-\mathrm{NMR}$ $\left(\right.$ DMSO- $d_{6}$ ) $\delta 18.01,51.82,52.62,119.25,123.07,128.82$, 129.26, 133.07, 134.16, 148.18, 165.50. HRMS calculated for $\mathrm{C}_{20} \mathrm{H}_{17} \mathrm{ClF}_{3} \mathrm{~N}_{3} \mathrm{O}_{2} \mathrm{~S} 455.0682$, found $456.0792(\mathrm{M}+\mathrm{H})^{+}$.

Methyl 2-(4-bromophenylamino)-4-(4-chlorophenyl)6-methyl-I,4-dihydropyrimidine-5-carboxylate (compound DHPM6)

Appearance: pale yellow solid. ${ }^{1} \mathrm{H}-\mathrm{NMR}$ (DMSO- $\left.d_{6}\right) \delta 2.08$ $\left(\mathrm{s}, 3 \mathrm{H},-\mathrm{CH}_{3}\right), 3.63\left(\mathrm{~s}, 3 \mathrm{H},-\mathrm{OCH}_{3}\right), 5.41(\mathrm{~s}, 1 \mathrm{H}), 7.17$ (d, 2H), $7.18(\mathrm{~d}, 2 \mathrm{H}), 7.47$ (d, 2H), $7.6(\mathrm{~d}, 2 \mathrm{H}), 9.93(\mathrm{~s}, 1 \mathrm{H})$,

Table I Physicochemical characteristics of the compounds DHPMI-DHPM8

\begin{tabular}{|c|c|c|c|c|c|}
\hline Compound & $\mathbf{A r}$ & $\begin{array}{l}\text { Molecular formula } \\
\text { (molecular weight) }\end{array}$ & Yield (\%) & $\begin{array}{l}\text { Melting point } \\
\left({ }^{\circ} \mathrm{C}\right)\end{array}$ & $c \log P c$ \\
\hline DHPMI & $3-\mathrm{Br}-\mathrm{C}_{6} \mathrm{H}_{4}$ & $\mathrm{C}_{19} \mathrm{H}_{17} \mathrm{BrClN}_{3} \mathrm{O}_{2}(433)$ & 66 & $218-220$ & 6.0560 \\
\hline DHPM2 & $2-\mathrm{OH}, 4-\mathrm{NO}_{2}-\mathrm{C}_{6} \mathrm{H}_{3}$ & $\mathrm{C}_{19} \mathrm{H}_{17} \mathrm{CIN}_{4} \mathrm{O}_{5}(416)$ & 69 & $174-176$ & 4.8054 \\
\hline DHPM3 & $3-\mathrm{Br}, 4-\mathrm{F}-\mathrm{C}_{6} \mathrm{H}_{3}$ & $\mathrm{C}_{19} \mathrm{H}_{16} \mathrm{BrClFN}_{3} \mathrm{O}_{2}(45 \mathrm{I})$ & 73 & $238-240$ & 6.3049 \\
\hline DHPM4 & $4-\mathrm{CN}-\mathrm{C}_{6} \mathrm{H}_{4}$ & $\mathrm{C}_{20} \mathrm{H}_{17} \mathrm{CIN}_{4} \mathrm{O}_{2}(380)$ & 62 & $116-118$ & 5.0256 \\
\hline DHPM5 & $3-\mathrm{SCF}_{3}-\mathrm{C}_{6} \mathrm{H}_{4}$ & $\mathrm{C}_{20} \mathrm{H}_{17} \mathrm{ClF}_{3} \mathrm{~N}_{3} \mathrm{O}_{2} \mathrm{~S}(455)$ & 68 & $222-224$ & 6.5586 \\
\hline DHPM6 & $4-\mathrm{Br}-\mathrm{C}_{6} \mathrm{H}_{4}$ & $\mathrm{C}_{19} \mathrm{H}_{17} \mathrm{BrClN}_{3} \mathrm{O}_{2}(433)$ & 68 & $228-230$ & 6.0560 \\
\hline DHPM7 & $3-\mathrm{Cl}, 5-\mathrm{OH}-\mathrm{C}_{6} \mathrm{H}_{3}$ & $\mathrm{C}_{19} \mathrm{H}_{17} \mathrm{Cl}_{2} \mathrm{~N}_{3} \mathrm{O}_{3}(405)$ & 66 & $200-202$ & 4.3300 \\
\hline DHPM8 & 2,4- $\mathrm{OCH}_{3}$-benzyl & $\mathrm{C}_{22} \mathrm{H}_{24} \mathrm{CIN}_{3} \mathrm{O}_{4}(429)$ & 74 & $222-224$ & 5.3218 \\
\hline
\end{tabular}

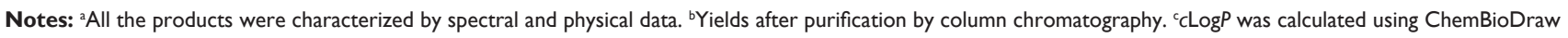
Ultra 13.0v.

Abbreviation: DHPM, dihydropyrimidine. 


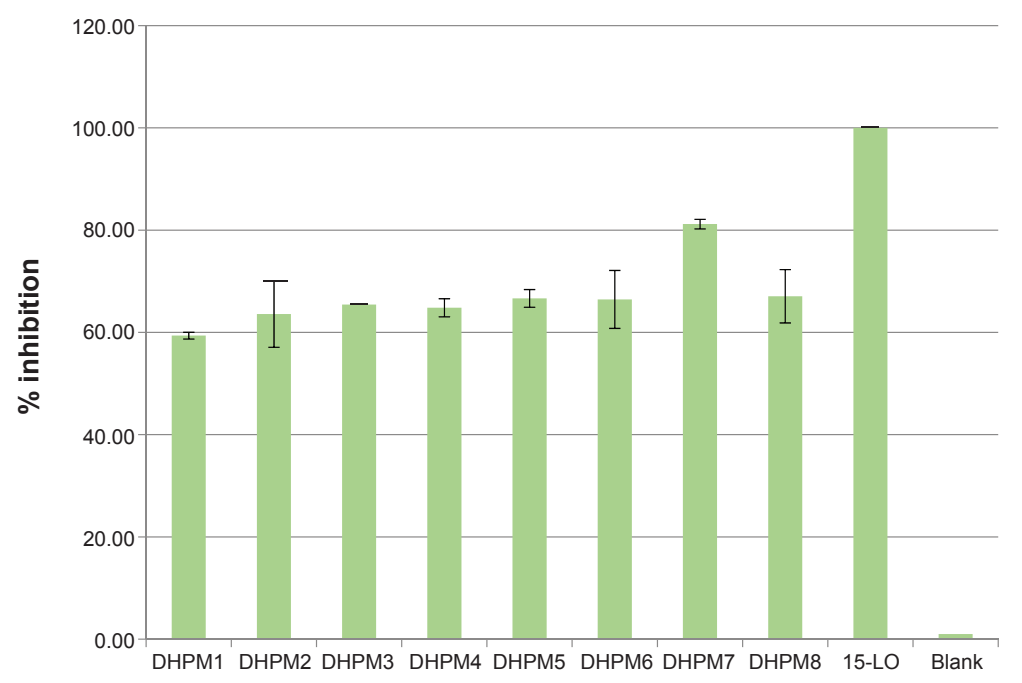

Figure 2 15-Lipoxygenase inhibitory rate of DHPMI-DHPM8.

Notes: Data are presented as mean \pm standard deviation of three replicates from three independent experiments. Blank is assay with buffer alone without test compounds. Abbreviations: 15-LO, I5-lipoxygenase inhibitor; DHPM, dihydropyrimidine.

$10.83(\mathrm{~s}, 1 \mathrm{H}) .{ }^{13} \mathrm{C}-\mathrm{NMR}$ (DMSO- $\left.d_{6}\right) \delta 18.02,52.11,52.14$, $103.72,120.29,127.07,128.07,128.98,129.40,132.13$, 133.24, 133.44, 134.09, 140.58, 145.24, 149.29, 165.09 . HRMS calculated for $\mathrm{C}_{19} \mathrm{H}_{17} \mathrm{BrClN}_{3} \mathrm{O}_{2} 433.0193$, found $434.0294(\mathrm{M}+\mathrm{H})^{+}$.

Methyl 2-(3-chloro-5-hydroxyphenylamino)-4-(4chlorophenyl)-6-methyl- I,4-dihydropyrimidine-5carboxylate (compound DHPM7)

Appearance: white solid. ${ }^{1} \mathrm{H}-\mathrm{NMR}\left(\mathrm{DMSO}-d_{6}\right) \delta 2.40(\mathrm{~s}$, $\left.3 \mathrm{H},-\mathrm{CH}_{3}\right), 3.59\left(\mathrm{~s}, 3 \mathrm{H},-\mathrm{OCH}_{3}\right), 5.33(\mathrm{~s}, 1 \mathrm{H}), 6.77(\mathrm{~s}, 2 \mathrm{H})$, 7.29-7.45 (m, 5H), $10.18(\mathrm{~s}, 2 \mathrm{H}) .{ }^{13} \mathrm{C}-\mathrm{NMR}$ (DMSO- $d_{6}$ ) $\delta 18.17,51.93,52.53,102.85,115.62,116.80,119.39$, $129.13,129.16,131.14,133.21,141.07,145.75,149.26$, 157.86, 165.24. HRMS calculated for $\mathrm{C}_{19} \mathrm{H}_{17} \mathrm{Cl}_{2} \mathrm{~N}_{3} \mathrm{O}_{3}$ 405.0647, found 406.0726 $(\mathrm{M}+\mathrm{H})^{+}$.

Methyl 4-(4-chlorophenyl)-2-(2,4dimethoxybenzylamino)-6-methyl- I,4dihydropyrimidine-5-carboxylate (compound DHPM8) Appearance: pale yellow solid. ${ }^{1} \mathrm{H}-\mathrm{NMR}\left(\mathrm{DMSO}-d_{6}\right) \delta 2.37$ $\left(\mathrm{s}, 3 \mathrm{H},-\mathrm{CH}_{3}\right), 3.60\left(\mathrm{~s}, 3 \mathrm{H},-\mathrm{OCH}_{3}\right), 3.75(\mathrm{~s}, 6 \mathrm{H}), 4.27(\mathrm{~m}$, $2 \mathrm{H}), 5.43(\mathrm{~s}, 1 \mathrm{H}), 6.42(\mathrm{~d}, 1 \mathrm{H}), 6.56(\mathrm{~s}, 1 \mathrm{H}), 7.11(\mathrm{~d}, 1 \mathrm{H})$, $7.28(\mathrm{~d}, 2 \mathrm{H}), 7.42(\mathrm{~d}, 2 \mathrm{H}), 9.95(\mathrm{~s}, 1 \mathrm{H}), 10.77(\mathrm{~s}, 1 \mathrm{H}) .{ }^{13} \mathrm{C}-$ NMR (DMSO- $\left.d_{6}\right) \delta 18.14,51.72,51.93,55.72,55.92,98.97$, $102.01,104.77,116.39,128.92,129.17,130.16,133.20$, 141.01, 145.78, 150.20, 158.54, 161.16, 165.27. HRMS calculated for $\mathrm{C}_{22} \mathrm{H}_{24} \mathrm{ClN}_{3} \mathrm{O}_{4} 429.1455$, found 430.1552 $(\mathrm{M}+\mathrm{H})^{+}$.

\section{Molecular modeling} Molecular alignment

The molecular alignment was done using MOE 2013.08 for the alignment of both 5-lipoxygenase and 15-lipoxygenase with protein data bank (PDB) codes $3 \mathrm{~V} 99$ and 4NRE, respectively.

\section{Molecular docking studies with MOE 2013.08}

All the compounds were built and saved as MOE files. (4S)-2(Substituted-phenyl/or benzyl)-4-(4-chlorophenyl)-6-methyl5-methyl carboxylate-1,4-dihydropyrimidine enantiomer was used for docking process. Rigid receptor was used as a docking protocol. Both the receptor and the solvent were kept as a "receptor". Triangle matcher was used as a placement method. Two rescoring were computed, rescoring 1 was selected as London $\mathrm{dG}$, rescoring 2 was selected as affinity. Force field was used as a refinement.

\section{Molecular docking studies with Leadit 2.I.2}

All compounds were built and saved as mol2 files. (4S)2-(substituted-phenyl/or benzyl)-4-(4-chlorophenyl)-6 -methyl-5-methyl carboxylate-1,4-dihydropyrimidine enantiomer was used for docking process. The crystal structure of lipoxygenase enzyme complexed with arachidonic acid was downloaded from PDB (code =3V99). The protein was loaded into Leadit 2.1.2, and the receptor components were chosen by selection of chain A as a main chain, which is complexed with arachidonic acid. Binding site was defined by choosing arachidonic acid as a reference ligand, 
to which all coordinates were computed. Amino acids within radius $6.5 \AA$ were selected in the binding site. All chemical ambiguities of residues were left as default. Ligand binding was driven by enthalpy (classic Triangle matching). For scoring, all default settings were restored. Intraligand clashes were computed by using clash factor $=0.6$. Maximum number of solutions per iteration $=200$. Maximum solution per fragmentation $=200$. The base placement method was used as a docking strategy. Docking results are tabulated in Table 2 .

\section{Pharmacology Lipoxygenase inhibitory assay}

The assay was done using the lipoxygenase Inhibitor Screening Assay Kit (Cayman Chemicals, Ann Arbor, MI, USA). The assay was performed following the manufacturer's protocol. Briefly, lipoxygenases are dioxygenases that catalyze the addition of oxygen to unsaturated fatty acids, which contain a cis,cis-1,4-pentadiene system. ${ }^{27}$ The activity of DHPM1DHPM8 was determined at $1 \mathrm{mg} / \mathrm{mL}$ using 15-lipoxygenase as standard positive control. The $100 \%$ initial inhibitor activity was determined using the lipoxygenase enzyme and solvent DMSO, which was used to dissolve the inhibitor. The inhibitor (DHPM1-DHPM8) activity was determined by adding lipoxygenase enzyme to the inhibitor. The reaction was initiated by the addition of the substrate, arachidonic acid, to all wells. Chromogen was added to all wells to stop enzyme catalysis and to develop the reaction. The plate was covered with a plate cover and the product of the enzymatic reaction was determined spectrophotometrically at 490-500 $\mathrm{nm}$.
Lipoxygenase results are presented in Table 3, the percentage inhibition is depicted in Figure 2 and it was determined using the following equation:

$$
\% \text { inhibition }=\frac{\text { Initial activity }- \text { Inhibitor }}{\text { Initial activity }} \times 100
$$

\section{Cell culture}

Two human cancer cell lines such as MCF-7 and UACC-62 (human melanoma cell) were provided by The Council for Scientific and Industrial Research Biosciences, Pretoria, South Africa. The cells were cultured in Dulbecco's Modified Eagle's Medium, supplemented with 10\% (v/v) fetal calf serum and $100 \mu \mathrm{g} / \mathrm{mL}$ streptomycin and 100 units $/ \mathrm{mL}$ penicillin in humidified $5 \% \mathrm{CO}_{2}$ at $37^{\circ} \mathrm{C}$. The PBMCs were separated, stored according to reported protocol, ${ }^{28}$ and grown aseptically in tissue culture flasks $\left(\mathrm{T} 75 \mathrm{~cm}^{2}\right)$ using medium that comprised RPMI-1640, heat-inactivated filtered fetal calf serum $(50 \mathrm{~mL}), 100 \mu \mathrm{g} / \mathrm{mL}$ streptomycin, and 100 units $/ \mathrm{mL}$ penicillin. The cultures were incubated in humidified $5 \%$ $\mathrm{CO}_{2}$ incubator at $37^{\circ} \mathrm{C}$.

\section{Cytotoxic activity}

The in vitro cytotoxicity of the compounds DHPM1-DHPM8 was screened against UACC-62 and MCF-7 tumor cell lines and peripheral blood mononuclear cell line using the MTT assay. ${ }^{29}$ The assay was carried out in 96-well, flat-bottomed microtiter plates. A volume of $90 \mu \mathrm{L}$ of $\pm 1 \times 10^{4}$ cells was added to each well, and $10 \mu \mathrm{L}$ of the test compounds $(50 \mu \mathrm{g} / \mathrm{mL})$ were added to the respective wells. In the control

Table 2 Docking results of the synthesized compounds DHPMI-DHPM8 against human lipoxygenase in complex with arachidonic acid

\begin{tabular}{|c|c|c|c|c|c|}
\hline Compound & $\begin{array}{l}\text { Docking score } \\
\text { using MOE } 2013.08\end{array}$ & $\begin{array}{l}\text { Main residue } \\
\text { that interacts }\end{array}$ & $\begin{array}{l}\text { Main } \\
\text { pharmacophore }\end{array}$ & Distance (A) & $\begin{array}{l}\text { Binding free energy } \\
\text { (kcal/mol) }\end{array}$ \\
\hline \multirow[t]{2}{*}{ DHPMI } & -5.29 & Phe 177 & $-\mathrm{C}=\mathrm{O}$ of ester & 3.09 & -11.5 \\
\hline & & $\mathrm{HOH} 922$ & $\mathrm{~N}=\mathrm{C}$ of pyrimidine ring & 3.20 & -2.5 \\
\hline \multirow[t]{2}{*}{ DHPM2 } & -5.40 & $G \ln 363$ & $-\mathrm{NH}$ of pyrimidine & 3.5 & -1 \\
\hline & & $\mathrm{HOH} 922$ & $-\mathrm{C}=\mathrm{O}$ of ester & 2.83 & -1.3 \\
\hline \multirow[t]{2}{*}{ DHPM3 } & -5.8 & Phe 177 & $\mathrm{~N}=\mathrm{C}$ of pyrimidine ring & 3.02 & -14.04 \\
\hline & & $\mathrm{HOH} 931$ & $-\mathrm{C}=\mathrm{O}$ of ester & 3.17 & -1.1 \\
\hline \multirow[t]{2}{*}{ DHPM4 } & -5.7 & Leu 368 & $\mathrm{~N}$ atom of cyano group & 3.71 & -0.8 \\
\hline & & Phe 177 & HN-Phenyl & 3.15 & -13.6 \\
\hline DHPM5 & -5.9 & Phe 177 & $-\mathrm{C}=\mathrm{O}$ of ester & 3.34 & -7.3 \\
\hline \multirow[t]{2}{*}{ DHPM6 } & -6.12 & Ile 406 & HN-Phenyl & 3.58 & -0.7 \\
\hline & & Phe 177 & $\mathrm{~N}=\mathrm{C}$ & 3.02 & -14.9 \\
\hline \multirow[t]{2}{*}{ DHPM7 } & -6.42 & Gln 363 & $\mathrm{NH}$ of pyrimidine ring & 3.37 & -11.8 \\
\hline & & $\mathrm{HOH} 955$ & HN-Phenyl & 3.42 & -2.0 \\
\hline DHPM8 & -6.32 & Phe 177 & $\mathrm{C}=\mathrm{O}$ of ester & 2.89 & -10.55 \\
\hline
\end{tabular}

Abbreviations: MOE, Molecular Operating Environment; DHPM, dihydropyrimidine. 
Table 3 I5-Lipoxygenase inhibitor assay of compounds DHPMIDHPM8

\begin{tabular}{lll}
\hline Compound & $\begin{array}{l}\text { Concentration of test } \\
\text { compounds }(\mu \mathrm{M})\end{array}$ & $\begin{array}{l}\text { Lipoxygenase } \\
\text { inhibition }(\%)\end{array}$ \\
\hline DHPMI & 2.30 & $59.37 \pm 0.66$ \\
DHPM2 & 2.40 & $63.60 \pm 6.50$ \\
DHPM3 & 2.21 & $65.44 \pm 0.00$ \\
DHPM4 & 2.63 & $64.83 \pm 1.77$ \\
DHPM5 & 2.19 & $66.66 \pm 1.73$ \\
DHPM6 & 2.30 & $66.46 \pm 5.67$ \\
DHPM7 & 2.46 & $81.19 \pm 0.94$ \\
DHPM8 & 2.33 & $67.08 \pm 5.22$ \\
I5-LO & 3.19 & $100.00 \pm 0.0$ \\
\hline
\end{tabular}

Abbreviations: DHPM, dihydropyrimidine; I5-LO, I5-lipoxygenase inhibitor.

wells, DMSO and media were added. The positive controls used were doxorubicin and camptothecin at $50 \mu \mathrm{g} / \mathrm{mL}$. The plates were incubated at $37^{\circ} \mathrm{C}$ with $5 \% \mathrm{CO}_{2}$ for 48 hours. After incubation, $20 \mu \mathrm{L}$ of MTT reagent was added and the plates were then incubated for a further 4 hours at $37^{\circ} \mathrm{C}$ in a humidified incubator with $5 \% \mathrm{CO}_{2}$. After incubation, $100 \mu \mathrm{L}$ of DMSO was added to each well and the plate was incubated for 1 hour at $37^{\circ} \mathrm{C}$ in a humidified incubator with $5 \% \mathrm{CO}_{2}$. The absorbance was read at $590 \mathrm{~nm}$ on an enzymelinked immunosorbent assay plate reader (Digital Analogue Systems, Italy), and the results are tabulated in Table 4. The percentage of cell viability and percentage of growth inhibition were determined using the following formulas:

$$
\% \text { cell viability }=\frac{\text { Absorbance of treated cells }}{\text { Absorbance of untreated cells }} \times 100
$$

$\%$ growth inhibition $=100-\%$ cell viability

Further test compounds that exhibited over $80 \%$ cell growth inhibition on UACC-62 and MCF-7 tumor cell lines were used to determine half-maximal inhibitory concentration, which was determined from the chart of cell viability percentage against test compounds concentration $(\mu \mathrm{M})$ (Table 5).

\section{Statistical analysis}

Each experiment was performed in triplicate, and the data are presented as mean \pm standard deviation. Using analysis of variance, statistical significance was determined and mean values with probability values of $P<0.05$ were taken as statistically significant.

\section{Results and discussion Chemistry}

Figure 1 depicts the synthesis of 2,4,5-trisubstituted pyrimidine analogues DHPM1-DHPM8. Synthesis of intermediate 1 has been achieved by Biginelli reaction by retaining Lewis acid as a catalyst as described in the literature. ${ }^{26}$ Purification of the intermediate was achieved using methanol as a solvent for recrystallization method and the yield obtained was found to be $66 \%$. Intermediate 2 was synthesized by reacting the intermediate 1 with phosphorous oxychloride for 15 hours. Compound 2 was obtained at $75 \%$ yield after recrystallization using methanol. Compounds DHPM1DHPM8 were obtained by refluxing mono/disubstituted aromatic amines with intermediate 2 at equimolar proportion with potassium carbonate in isopropanol medium. The crude compounds were purified by column chromatography. The yield of the final compounds was in the range of $62 \%-74 \%$. Finally, the chemical structure of 1,4-dihydropyrimidine analogues DHPM1-DHPM8 was confirmed by ${ }^{1} \mathrm{H}-\mathrm{NMR}$, ${ }^{13} \mathrm{C}-\mathrm{NMR}$, and HRMS. In ${ }^{1} \mathrm{H}-\mathrm{NMR}$ of DHPM1-DHPM8, the ester methoxy and methyl group on heteroaryl ring exhibited chemical shift in the range of $\delta=3.59-3.63$ and $\delta=2.08-2.42 \mathrm{ppm}$, respectively. Single heterocyclic proton

Table 4 In vitro cytotoxicity of DHPMI-DHPM7 against MCF-7, UACC-62, and PBMC cell lines

\begin{tabular}{llll}
\hline Compound & \multicolumn{3}{l}{ Cell growth inhibition $\mathbf{( \% )}$ at $\mathbf{5 0} \boldsymbol{\mu g} / \mathbf{m L}$} \\
\cline { 2 - 4 } & MCF-7 & UACC-62 & PBMC \\
\hline DHPMI & $89.79 \pm 2.13$ & $97.57 \pm 0.14$ & $18.92 \pm 1.54$ \\
DHPM2 & $15.82 \pm 2.84$ & $82.62 \pm 0.86$ & $0.00 \pm 0.00$ \\
DHPM3 & $20.02 \pm 1.78$ & $39.62 \pm 0.21$ & $16.60 \pm 0.77$ \\
DHPM4 & $89.51 \pm 5.44$ & $97.47 \pm 0.14$ & $0.00 \pm 0.00$ \\
DHPM5 & $60.00 \pm 15.85$ & $97.22 \pm 0.07$ & $14.29 \pm 1.10$ \\
DHPM6 & $96.09 \pm 1.35$ & $97.04 \pm 1.28$ & $16.34 \pm 0.89$ \\
DHPM7 & $94.56 \pm 1.54$ & $96.72 \pm 0.50$ & $8.62 \pm 1.61$ \\
DHPM8 & $96.82 \pm 0.47$ & $98.89 \pm 0.43$ & $18.92 \pm 1.34$ \\
Camptothecin & $76.34 \pm 0.10$ & $92.46 \pm 1.24$ & $8.90 \pm 0.57$ \\
\hline
\end{tabular}

Note: Percentage of cell growth inhibition by the MTT assay after 48 hours of test compounds exposure at $50 \mu \mathrm{g} / \mathrm{mL}$ concentration.

Abbreviations: DHPM, dihydropyrimidine; MCF-7, Michigan Cancer Foundation-7; PBMC, peripheral blood mononuclear cell; UACC-62, human melanoma cells; MTT, 3-(4,5-dimethylthiazol-2-yl)-2,5-diphenyltetrazolium bromide. 
Table 5 In vitro cytotoxicity $\left(\mathrm{IC}_{50}\right)$ of the test compounds DHPMI-DHPM8 against MCF-7 and UACC-62

\begin{tabular}{lll}
\hline Compound & \multicolumn{1}{l}{ IC $_{50}(\mu M)^{\mathrm{a}, \mathrm{b}}$} & UACC-62 \\
\cline { 2 - 3 } & MCF-7 & $6.63 \pm 0.03$ \\
\hline DHPMI & $22.22 \pm 0.01$ & $21.4 \pm 0.31$ \\
DHPM2 & NT & NT \\
DHPM3 & NT & $6.21 \pm 0.02$ \\
DHPM4 & $17.45 \pm 0.01$ & $0.85 \pm 0.04$ \\
DHPM5 & NT & $12.77 \pm 0.01$ \\
DHPM6 & $7.02 \pm 0.01$ & $19.55 \pm 0.02$ \\
DHPM7 & $35.33 \pm 0.37$ & $1.97 \pm 0.08$ \\
DHPM8 & $0.92 \pm 0.09$ &
\end{tabular}

Note: ${ }^{a} C_{50}$ is the test samples (DHPMI-DHPM8) concentration effective in inhibiting $50 \%$ of the cell growth measured by the MTT assay after 48 hours of exposure to test compounds. 'Only compounds that exhibited over $80 \%$ of growth inhibition were taken for $\mathrm{IC}_{50}$ determination.

Abbreviations: DHPM, dihydropyrimidine; $\mathrm{IC}_{50}$, half-maximal inhibitory concentration; MCF-7, Michigan Cancer Foundation-7; MTT, 3-(4,5-dimethylthiazol2-yl)-2,5-diphenyltetrazolium bromide; NT, not tested; UACC-62, human melanoma cells.

is noticed in the range of $\delta=5.34-5.43 \mathrm{ppm}$. In ${ }^{13} \mathrm{C}-\mathrm{NMR}$, carbonyl carbon of ester functional group is observed in the range of $\delta=165.10-165.5 \mathrm{ppm}$. In HRMS, molecular ion peaks were in good agreement with the proposed molecular weight. $c \log P$ of the title compounds DHPM1-DHPM8 was calculated by ChemBioDraw Ultra 13.0v program, and the values were in the range of $4.3300-6.5586$.

\section{Molecular modeling study}

In order to explain the lipoxygenase inhibitory activity computationally, the crystal structure of human lipoxygenase was studied. Two crystal structures of both 5-lipoxygenase and 15-lipoxygenase were reported in PDB. ${ }^{30,31}$ The structure of human 5-lipoxygenase was complexed with arachidonic acid, which can help more in the identification of the main binding site of that enzyme. While, the human 15-lipoxygenase was found complexed with a substrate mimic, our compounds which were tested against 15-lipoxygenase were not complexed with arachidonic acid. A previous study confirmed that the two structures are similar, ${ }^{31}$ and both of them have the same conserved cavity with the same conserved amino acids at the binding site. They also have similar volume of the cavity. A molecular alignment of the crystal structures of 5-lipoxygenase with PDB code $=3$ V99 and 15-lipoxygenase with $\mathrm{PDB}$ code $=4 \mathrm{NRE}$ was done. The aim of this alignment was to identify the main binding site of both and to prove that they are the same (Figure 3).

According to the alignment results, both the structures have a homologous sequence. The same binding cavity for both arachidonic acid and substrate mimic was identified. The amino acids that are found in the main site are His 373, Ile 676, Ala 416, Asp 602, Asp 602, Ala 672, Glu 369, Val 426, Val 671, Ile 406, Leu 415, Phe 177, Gln 557, and Gln 413 in addition to water molecules $\mathrm{H}_{2} \mathrm{O} 995$ and $\mathrm{H}_{2} \mathrm{O} 922$ (Figure 4).

Molecular docking was done using MOE 2013.08 in which the (4S)-2-(substituted-phenyl/or benzyl)-4-(4chlorophenyl)-6-methyl-5-methyl carboxylate-1,4-dihydropyrimidine enantiomer was used for docking as it showed better results than the (4R)-2-(substituted-phenyl/or-benzyl)4-(4-chlorophenyl)-6-methyl-5-methyl carboxylate-1,4dihydropyrimidine enantiomer. Docking resulted in a number of docking scores (Table 2), which were parallel to the biological results (Figure 5). For example; the docking score

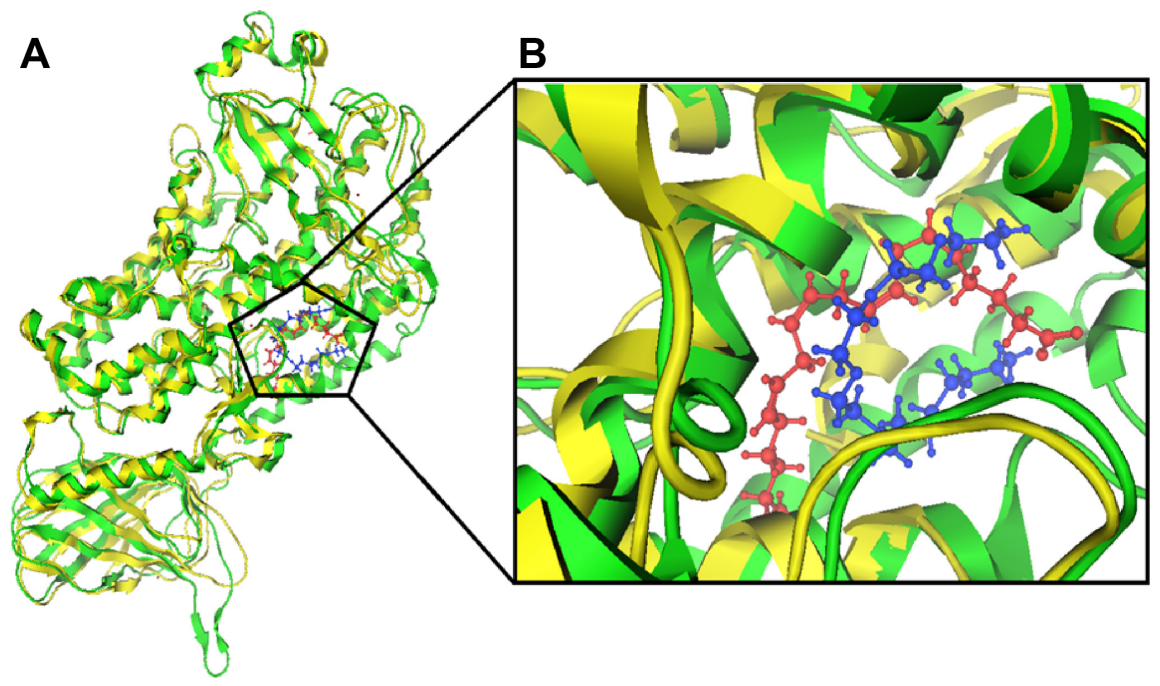

Figure 3 Sequence alignment between (A) 5-lipoxygenase (yellow color) complexed with arachidonic acid (red color) and (B) I5-lipoxygenase (green color) complexed with a substrate mimic (blue color).

Note: The two structures are represented as sketches. 

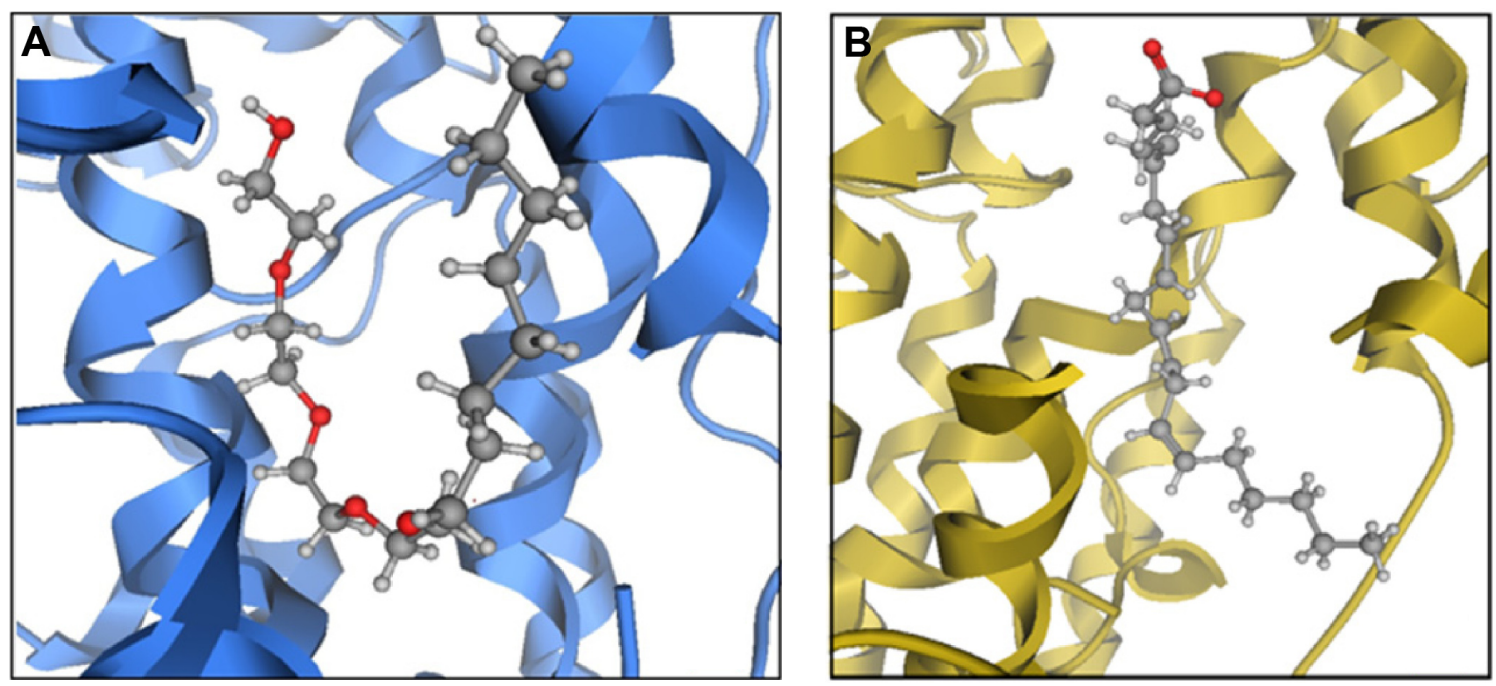

Figure 4 (A) The substrate that mimics arachidonic acid and its binding mode in 15-lipoxygenase. (B) Binding mode of arachidonic acid in human lipoxygenase. Notes: Compounds are represented as element color (red for oxygen, gray for carbon and white for hydrogen). Backbone is represented as cartoon.

for compound DHPM7 was the highest $=-6.42 \mathrm{kcal} / \mathrm{mol}$ and also had the highest percent of lipoxygenase inhibition $=81.19 \% \pm 0.94 \%$. This compound showed a hydrogen bond with Gln 363 with its -NH group of the pyrimidine ring with a distance $=3.37 \AA$. The binding free energy of this conformation was high compared to the other compounds and a direct contact with a water molecule $\mathrm{H}_{2} \mathrm{O} 955$ that is close to arachidonic acid with the aniline $-\mathrm{NH}$ group. Molecular docking of compound DHPM7 with Leadit 2.1.25 showed two poses; the first one revealed a hydrogen bond between His 367 with the $\mathrm{C}=\mathrm{O}$ group of the carboxylate side chain, in addition to the interaction of hydroxyl group with both $\mathrm{Fe}^{2+}$ and Val 671 (Figure 6A). The second pose of DHPM7 showed two hydrogen bonds between $\mathrm{C}=\mathrm{O}$ of carboxylate side chain and two $-\mathrm{NH}_{2}$ groups of both Phe 177 and Gln 413 (Figure 6B).

Molecular docking of the compound DHPM8 with Leadit 2.1.2 ${ }^{25}$ software showed two binding modes with different residues in the active site of the enzyme such as $\mathrm{Fe}^{2+}$ ion and Ala 672 (Figure 7A). In another pose, it showed a hydrogen bond with both Val 671 and Ala 672 and Asn 554 (Figure 7B).

The placement of the best pose of the most active compound DHPM7 inside the active site was compared to that of arachidonic acid (Figure 8). This figure provides good insights of the hydrophilic and hydrophobic regions of the pocket. Also, it showed how the best conformation of DHPM7 can fill in the total space of the pocket in

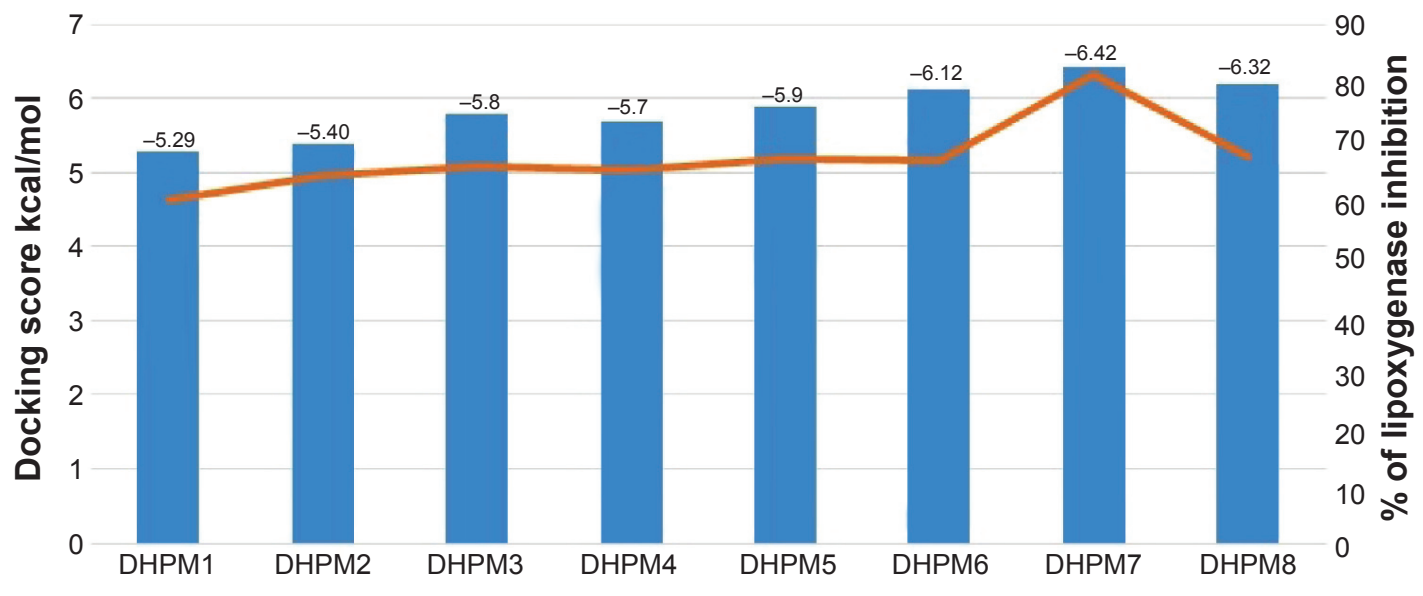

Docking score $\mathrm{kcal} / \mathrm{mol}$

Lipoxygenase inhibition \%

Figure 5 A correlation between the docking and biological results showing a high similarity between the experimental and computational results was observed. 

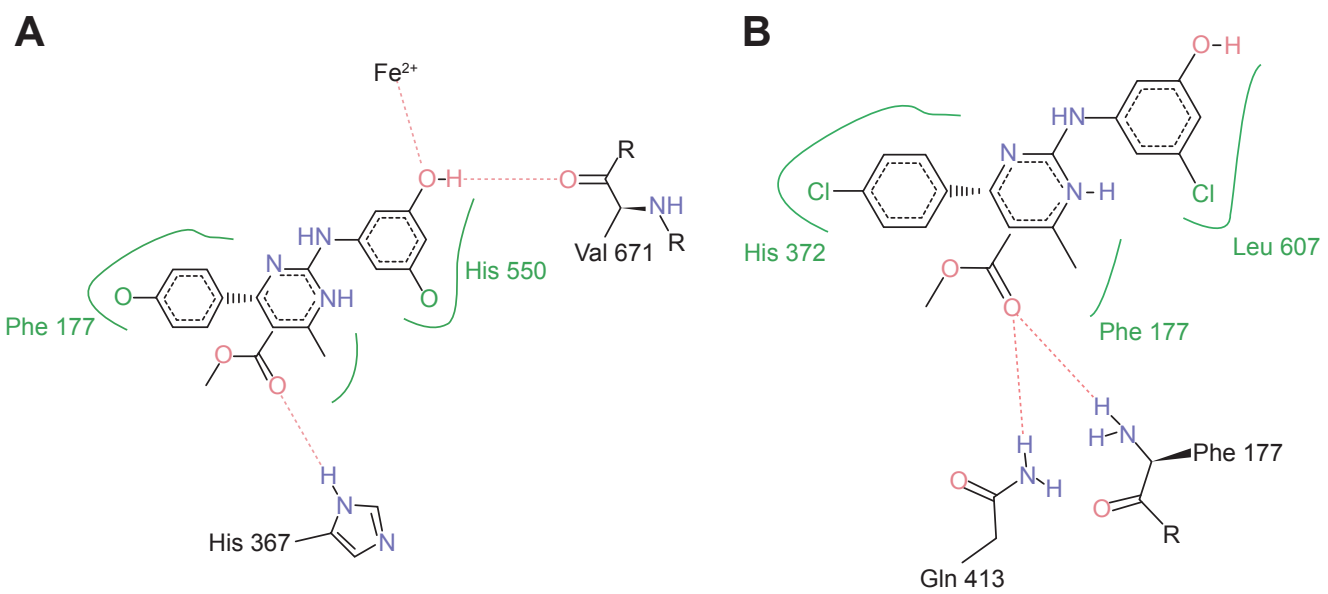

Figure 6 Two different binding modes for the compound dihydropyrimidines-7 resulting from Leadit 2.1.2 docking.

addition to excellent orientation of its groups toward the best interactions.

Both the inhibitory activity results of lipoxygenase and the molecular docking results confirmed the activity of these compounds as potential lipoxygenase inhibitors. These inhibitors may be of great importance in cancer inhibition, and this was confirmed by the use of two cancer cell lines such as breast cancer (MCF-7) and melanoma (UACC-62).

\section{Identification of the cytotoxic activity}

The title compounds were screened at $50 \mu \mathrm{g} / \mathrm{mL}$ concentration against MCF-7, UACC-62, and PBMC cell lines for cytotoxicity after 48 hours of treatment. From the percentage of cell growth inhibition values (Table 4), it was apparent that most of the test compounds exhibited promising anticancer activities compared to standard drugs (Figure 9). It was observed for the MCF-7 cell line that DHPM1, DHPM4, and DHPM6-8 displayed cytotoxicity over $89.51 \% \pm 5.44 \%$ after 48 hours. However, the compound DHPM2 bearing 2-hydroxy at second and nitro at fourth position of phenyl ring exhibited $15.82 \% \pm 2.84 \%$ against $\mathrm{MCF}-7$ cell lines, whereas the compound DHPM3 having bromine and fluorine atoms at the third and fourth positions, respectively, on the phenyl ring exhibited $20.02 \% \pm 1.78 \%$ against MCF- 7 cell lines. The title compounds at $50 \mu \mathrm{g} / \mathrm{mL}$ were noted to be very effective against the UACC-62 cell line with DHPM2 having a cytotoxicity value of $82.62 \% \pm 0.86 \%$ and DHPM1 and DHPM4-8 having cytotoxicity above $96.72 \% \pm 0.50 \%$. However, the compound DHPM3 having bromine and fluorine atoms at the third and fourth positions, respectively, on the phenyl ring exhibited $39.62 \% \pm 0.21 \%$ against UACC-62 cell lines when compared to other analogues in the series (Figure 9). The DHPM analogues were not toxic to PBMCs on comparing the activity of the DHPM to MCF-7 and UACC-62.
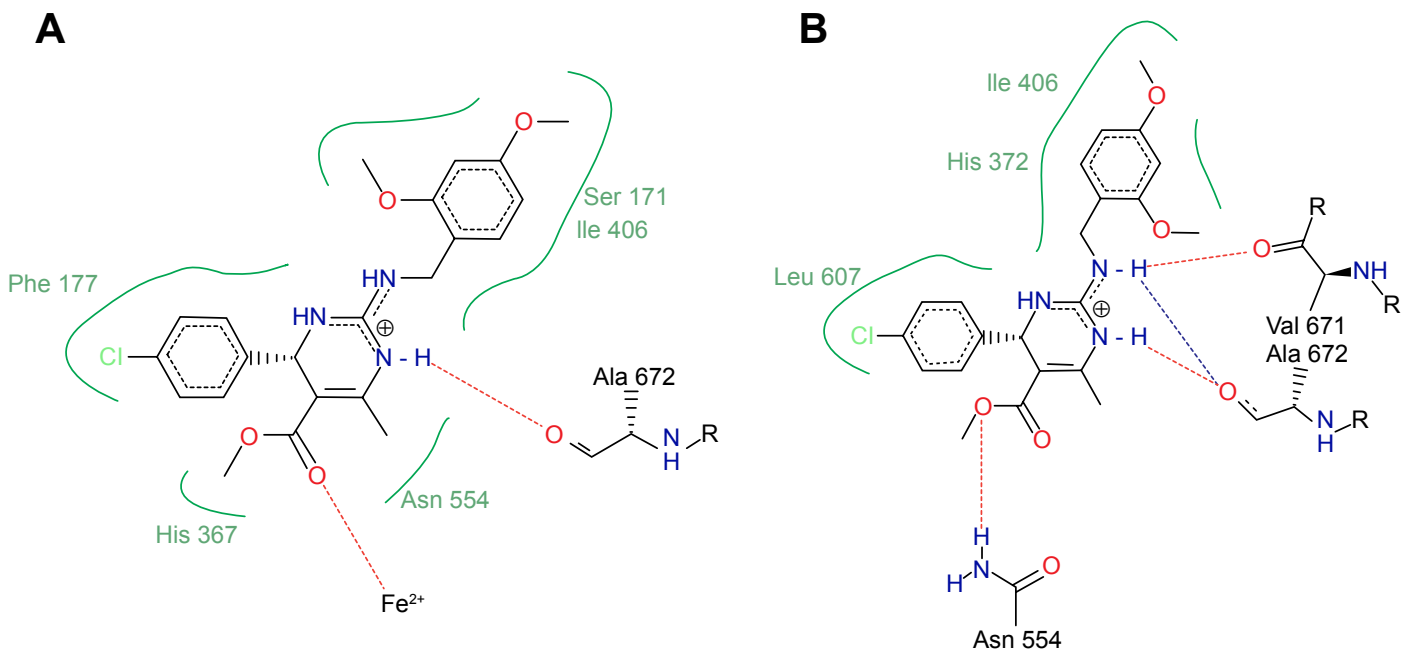

Figure 7 Binding modes of compound dihydropyrimidine- 8 in the active site. 
A

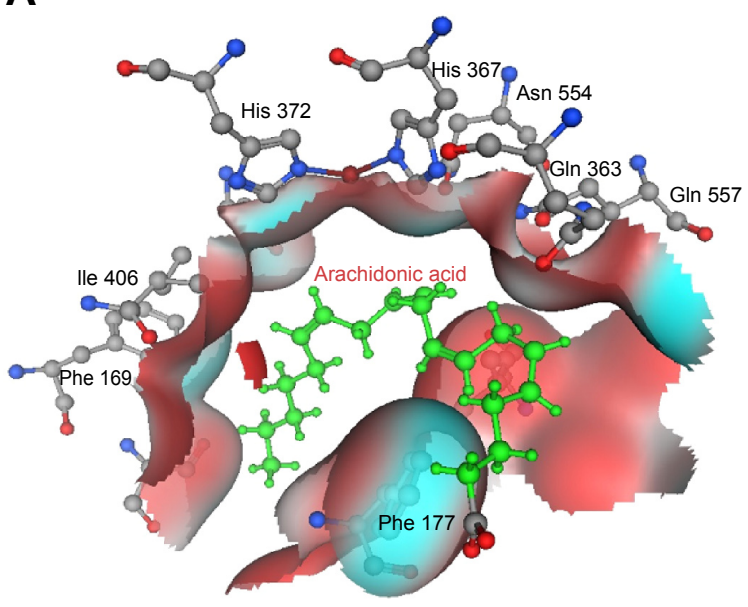

B

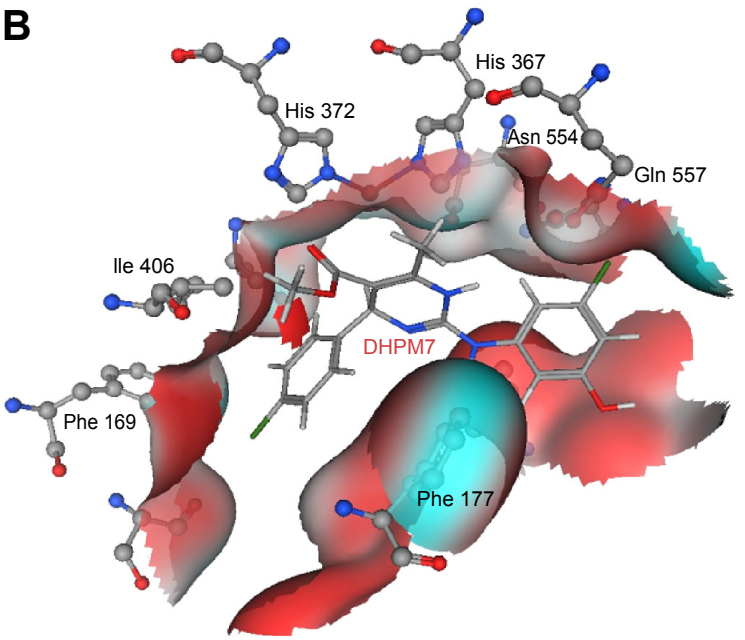

Figure 8 A comparative binding mode between $(\mathbf{A})$ arachidonic acid and (B) compound 7 inside the active site of the lipoxygenase. Note: The blue parts represent the mild polar parts and the red colored parts represent the nonpolar hydrophobic parts.

Abbreviation: DHPM, dihydropyrimidine.

The compound DHPM8 has the methoxy group at the second and fourth positions on the benzyl ring and exhibited half-maximal inhibitory concentration values of $0.92 \pm 0.09 \mu \mathrm{M}$ and $1.97 \pm 0.08 \mu \mathrm{M}$ against MCF-7 and UACC-62 cell lines, respectively, according to Table 5. According to our findings, compound DHPM7 and DHPM8 exhibited promising lipoxygenase enzyme inhibition activity and anticancer activity as predicted.

\section{Conclusion}

In the present investigation, the synthesis and characterization of 1,4-dihydropyrimidine analogues DHPM1-DHPM8 resulted in good yields. Purity of the compounds was confirmed by HPLC, and it was more than $99 \%$. Structural elucidation was completed by NMR $\left({ }^{1} \mathrm{H}\right.$ and $\left.{ }^{13} \mathrm{C}\right)$ and HRMS studies. It was noted that the compound DHPM7 exhibited potential lipoxygenase enzyme inhibition activity of $81.19 \% \pm 0.94 \%$ at a concentration $2.46 \mu \mathrm{M}$. The activity of the compounds against lipoxygenase enzyme was interpreted by a molecular docking study. The cytotoxic activity of compound DHPM8 in terms of half-maximal inhibitory concentration was $0.92 \pm 0.09 \mu \mathrm{M}$ and $1.97 \pm 0.08 \mu \mathrm{M}$ versus human cancer cell lines MCF-7 and UACC-62, respectively. Further studies may be needed for more modification of the compound DHPM7 to obtain potent lipoxygenase inhibitor and cancer chemoprotective agents.

\section{Acknowledgments}

The authors are grateful to College of Clinical Pharmacy, King Faisal University, and Durban University of Technology for facilities. The funding institutions had no involvement in the study design; in the collection, analysis, and interpretation of data; in the writing of the manuscript; and in the decision to submit the manuscript for publication. One of the authors (RG)

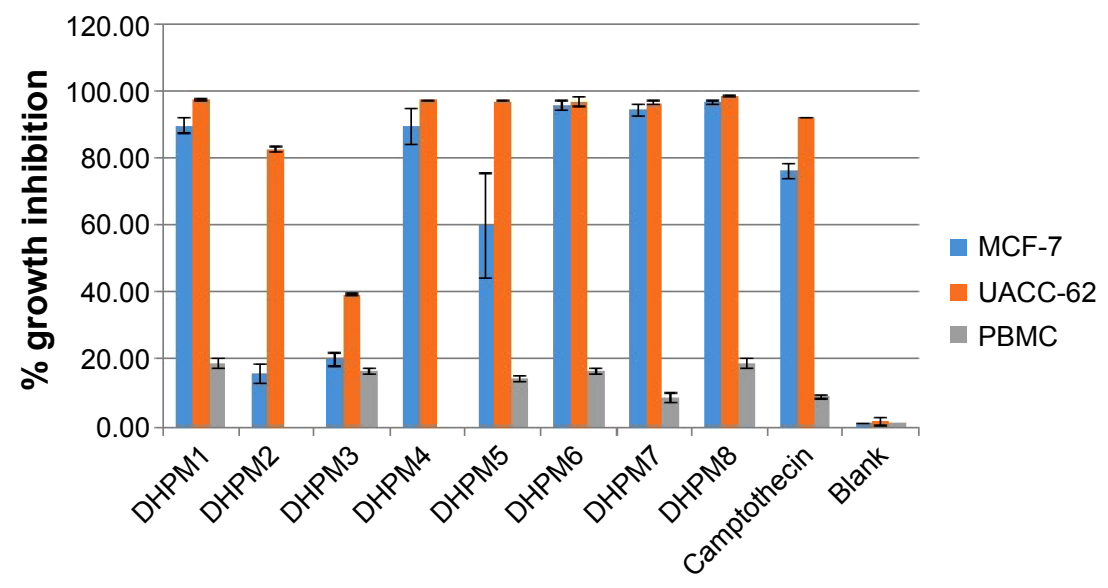

Figure 9 Percentage of growth inhibition of DHPMI-DHPM8 against MCF-7, UACC-62, and PBMC cell lines.

Note: Data are presented as mean \pm standard deviation at three replicates from three independent experiments. Blank, culture medium alone without test compounds. Abbreviations: MCF-7, Michigan Cancer Foundation-7; UACC-62, human melanoma cells; PBMC, peripheral blood mononuclear cell; DHPM, dihydropyrimidine. 
thanks the National Research Foundation (NRF), South Africa, for master's bursary (grant number 91944).

\section{Disclosure}

The authors report no conflicts of interest in this work.

\section{References}

1. Tron GC, Minassi A, Appendino G. Pietro Biginelli: the man behind the reaction. Eur J Org Chem. 2011;2011(28):5541-5550.

2. Kappe CO. Recent advances in the Biginelli dihydropyrimidine synthesis. New tricks from an old dog. Acc Chem Res. 2000;33(12):879-888.

3. Mishra R, Tomar I. Pyrimidine: the molecule of diverse biological and medicinal importance. Int J Pharm Sci Res. 2011;2:758-771.

4. Prashantha Kumar BR, Sankar G, Nasir Baig RB, Chandrashekaran S. Novel Biginelli dihydropyrimidines with potential anticancer activity: a parallel synthesis and CoMSIA study. Eur J Med Chem. 2009;44(10): 4192-4198.

5. Gößnitzer E, Feierl G, Wagner U. Synthesis, structure investigations, and antimicrobial activity of selected s-trans-6-aryl-4-isopropyl-2$\{2-[(E)-1$-phenylalkylidene]-(E)-hydrazino $\}$-1,4-dihydropyrimidine hydrochlorides. Eur J Pharm Sci. 2002;15(1):49-61.

6. Sedaghati B, Fassihi A, Arbabi S, Ranjbar M, Saghaie L, Sardari A. Synthesis and antimicrobial activity of novel derivatives of Biginelli pyrimidines. Med Chem Res. 2012;21:3973-3983.

7. Devi K, Venugopala KN, Rao GK. Synthesis of substituted 3,4dihydropyrimidine-2 $(1 H)$-thiones and their biological activity. Ind $J$ Het Chem. 2009;18:305-306.

8. Mohamed MS, Youns MM, Ahmed NM. Synthesis, antimicrobial, antioxidant activities of novel 6-aryl-5-cyano thiouracil derivatives. Eur J Med Chem. 2013;69:591-600.

9. Venugopala KN, Nayak SK, Pillay M, Prasanna R, Coovadia YM, Odhav B. Synthesis and antitubercular activity of 2-(substituted phenyl/ benzyl-amino)-6-(4-chlorophenyl)-5-(methoxycarbonyl)-4-methyl-3,6dihydropyrimidin-1-ium chlorides. Chem Biol Drug Des. 2013;81(2): 219-227.

10. Trivedi AR, Bhuva VR, Dholariya BH, Dodiya DK, Kataria VB, Shah VH. Novel dihydropyrimidines as a potential new class of antitubercular agents. Bioorg Med Chem Lett. 2010;20(20):6100-6102.

11. Chan DC, Laughton CA, Queener SF, Stevens MF. Structural studies on bioactive compounds. Part 36: design, synthesis and biological evaluation of pyrimethamine-based antifolates against Pneumocystis carinii. Bioorg Med Chem. 2002;10(9):3001-3010.

12. Martin JA, Bushnell DJ, Duncan IB, et al. Synthesis and antiviral activity of monofluoro and difluoro analogues of pyrimidine deoxyribonucleosides against human immunodeficiency virus (HIV-1). J Med Chem. 1990;33(8):2137-2145.

13. Guillemont J, Pasquier E, Palandjian P, et al. Synthesis of novel diarylpyrimidine analogues and their antiviral activity against human immunodeficiency virus type 1. J Med Chem. 2005;48(6):2072-2079.

14. Tale RH, Rodge AH, Hatnapure GD, Keche AP, Patil KM, Pawar RP. The synthesis, anti-inflammatory and antimicrobial activity evaluation of novel thioanalogs of 3,4-dihydrothiopyrimidin-2(1H)-one derivatives of $N$-aryl urea. Med Chem Res. 2012;21:4252-4260.
15. Rioux N, Castonguay A. Inhibitors of lipoxygenase: a new class of cancer chemopreventive agents. Carcinogenesis. 1998;19(8):1393-1400.

16. Aparoy P, Reddy KK, Reddanna P. Structure and ligand based drug design strategies in the development of novel 5-LOX inhibitors. Curr Med Chem. 2012;19:3763-3778.

17. Steele VE, Holmes CA, Hawk ET, et al. Lipoxygenase inhibitors as potential cancer chemopreventives. Cancer Epidemiol Biomarkers Prev. 1999;8(5):467-483.

18. Venugopala KN, Jayashree BS. Synthesis and characterization of Schiff bases of aminothiazolyl bromocoumarin for their analgesic and antiinflammatory activity. Asian J Chem. 2004;16(1):407-411.

19. Venugopala KN, Krishnappa M, Nayak SK, et al. Synthesis and antimosquito properties of 2,6-substituted benzo[ $d]$ thiazole and 2,4substituted benzo[d] thiazole analogues against Anopheles arabiensis. Eur J Med Chem. 2013;65(0):295-303.

20. Venugopala KN, Rao GK, Pai PNS, Ganesh GL. Synthesis and characterization of carboxamides of 2'-amino-4'-(3-2H-1-benzopyran-2-one) thiazole as anti-microbial agents. Asian J Chem. 2008;20(3):1697-1701.

21. Panini P, Venugopala KN, Odhav B, Chopra D. Polymorphism in two biologically active dihydropyrimidinium hydrochloride derivatives: quantitative inputs towards the energetics associated with crystal packing. Acta Crystallogr B Struct Sci Cryst Eng Mater. 2014;70(pt 4):681-696.

22. Munshi P, Venugopala KN, Jayashree BS, Guru Row TN. Concomitant polymorphism in 3-acetylcoumarin: role of weak $\mathrm{C}-\mathrm{H} \cdots \mathrm{O}$ and $\mathrm{C}-\mathrm{H} \cdots \pi$ interactions. Cryst Growth Des. 2004;4(6):1105-1107.

23. Chemical Computing Group Inc. Molecular Operating Environment (MOE). Montreal, QC: Chemical Computing Group Inc; 2013.

24. Biosolveit. Sankt Augustin, Germany: Biosolveit GmbH; 2014. Available from: http://www.biosolveit.de/

25. Rarey M, Kramer B, Lengauer T, Klebe G. A fast flexible docking method using an incremental construction algorithm. J Mol Biol. 1996; 261(3):470-489.

26. Nayak SK, Venugopala KN, Chopra D, Row TNG. Insights into conformational and packing features in a series of aryl substituted ethyl6-methyl-4-phenyl-2-oxo-1,2,3,4-tetrahydropyrimidine-5-carboxylates. Cryst Eng Comm. 2011;13:591-605.

27. Baylac $S$, Racine P. Inhibition of 5-lipoxygenase by essential oils and other natural fragrant extracts. Int J Aromather. 2003;13(2-3):138-142.

28. Malcolm Fisher. Isolation of peripheral blood mononuclear cells (PBMCs) from whole blood and subsequent culture of macrophage cells. July 2011. Available from: http://www.macrophages.com/ isolation-peripheral-blood-mononuclear-cells-pbmcs-whole-bloodand-subsequent-culture-macrophage-cel. Accessed May 14, 2014.

29. Mosmann T. Rapid colorimetric assay for cellular growth and survival: application to proliferation and cytotoxicity assays. J Immunol Methods. 1983;65(1-2):55-63.

30. Gilbert NC, Rui Z, Neau DB, et al. Conversion of human 5-lipoxygenase to a 15-lipoxygenase by a point mutation to mimic phosphorylation at Serine-663. FASEB J. 2012;26(8):3222-3229.

31. Kobe MJ, Neau DB, Mitchell CE, Bartlett SG, Newcomer ME. The structure of human 15-lipoxygenase-2 with a substrate mimic. J Biol Chem. 2014;289:8562-8569.

\section{Publish your work in this journal}

Drug Design, Development and Therapy is an international, peerreviewed open-access journal that spans the spectrum of drug design and development through to clinical applications. Clinical outcomes, patient safety, and programs for the development and effective, safe, and sustained use of medicines are a feature of the journal, which

\section{Dovepress}

has also been accepted for indexing on PubMed Central. The manuscript management system is completely online and includes a very quick and fair peer-review system, which is all easy to use. Visit http://www.dovepress.com/testimonials.php to read real quotes from published authors. 